\title{
URD12: A urea derivative with marked antitumor activities
}

\author{
AI-YUN WANG ${ }^{1,2}$, YIN LU ${ }^{2}$, HAI-LIANG ZHU ${ }^{1}$ and QING-CAI JIAO ${ }^{1}$ \\ ${ }^{1}$ State Key Laboratory of Pharmaceutical Biotechnology, Nanjing University; \\ ${ }^{2}$ College of Pharmacy, Nanjing University of Chinese Medicine, Nanjing, P.R. China
}

Received May 27, 2011; Accepted October 10, 2011

DOI: $10.3892 / \mathrm{ol} .2011 .474$

\begin{abstract}
Urea derivatives have been widely used in biology and medicine. The substituted urea derivative URD12 introduced in this study exhibits cytotoxic activity against the K562 human leukemia and KB human mouth epidermal carcinoma cell lines. To further study the bioactivity of URD12 and examine its feasibility as a new antitumor drug, we applied in vivo and in vitro assays to investigate the antitumor activity of URD12. URD12 was prepared and its cytotoxicity was evaluated using the BGC-823 human gastric carcinoma, MGC-803 human gastric carcinoma, SMMC-7721 human hepatoma and HepG2 human hepatocellular carcinoma cell lines using MTT assays. Antitumor activity in vivo was confirmed in mice bearing H22 hepatocellular carcinoma cells. Organ coefficient was used to further elucidate the cytotoxic mechanisms of URD12. URD12 inhibited the growth of tested tumor cell lines in vitro and the growth of $\mathrm{H} 22$ mouse hepatocellular carcinoma in vivo with no effects on the weight, spleen and thymus coefficient of tumor-bearing mice. In conclusion, our findings indicate that URD12 is an effective antitumor agent without evident immunosuppression effects.
\end{abstract}

\section{Introduction}

Urea is a well-known, widely occurring natural product. Its derivatives have been studied for their biological activities including anti-atherosclerotic, antibiotic (1) and hypoglycemic effects (2) and antitumor activities (3-12).

We have extensively studied urea and its derivatives. Among a series of substituted urea derivatives that we have synthesized, URD12 (Fig. 1) exhibits marked antitumor activity. With a morpholine ring, URD12 exhibits significant cytotoxic activity against the K562 human leukemia and KB human mouth epidermal carcinoma cell lines (13). To further investigate the bioactivity of URD12, we designed in vivo and in vitro experiments to examine its antitumor activity.

Correspondence to: Professor Hai-Liang Zhu, State Key Laboratory of Pharmaceutical Biotechnology, Nanjing University, Nanjing 210093, P.R. China

E-mail: zhuhl@nju.edu.cn

Key words: morpholine, antitumor, immune, urea derivative

\section{Materials and methods}

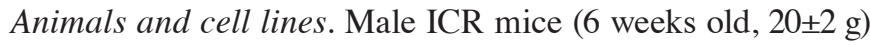
were obtained from the Experimental Animal Center of Nanjing University of Chinese Medicine. The animals were kept in groups of 6 per cage in a temperature-controlled room at $20 \pm 2^{\circ} \mathrm{C}$. The mice were fed with a standard pellet diet and given free access to tap water. All studies involving mice (including tumor cell inoculation and tumor weighing) were approved by the Institute's Animal Care and Use Committee.

The BGC-823 human gastric carcinoma, SMMC-7721 human hepatoma carcinoma, HepG2 human hepatocellular carcinoma and H22 mouse hepatocellular carcinoma cell lines were obtained from Professor Lu's laboratory (Nanjing University of Chinese Medicine) and cultured in RPMI-1640 with $10 \%$ fetal bovine serum, $100 \mathrm{U} / \mathrm{ml}$ streptomycin and penicillin.

Preparation of URD12. Anhydrous DMF (40 mmol) and $\mathrm{SOCl}_{2}$ $(0.10 \mathrm{~mol})$ were added to anhydrous $\mathrm{CH}_{2} \mathrm{Cl}_{2}(15 \mathrm{ml})$ and the resultant solution was stirred at reflux (approximately $70^{\circ} \mathrm{C}$ ) for $4 \mathrm{~h}$. After cooling down, the excess $\mathrm{SOCl}_{2}$ was evaporated under reduced pressure and the residue was dissolved in $\mathrm{CH}_{2} \mathrm{Cl}_{2}(15 \mathrm{ml})$ and anhydrous pyridine $(4 \mathrm{ml})$. A solution of $\mathrm{N}$-2-aminoethylmorphorine $\left(40 \mathrm{mmol}\right.$ ) in anhydrous $\mathrm{CH}_{2} \mathrm{Cl}_{2}$ was then added and the mixture was stirred at $50-60^{\circ} \mathrm{C}$ for $5 \mathrm{~h}$ before being poured into ice-water $(20 \mathrm{ml})$. The layers were separated and the aqueous layer was extracted with AcOEt (2x10 ml). The combined organic layer was washed with saturated aqueous $\mathrm{NaHCO}_{3}$ solution, dried over $\mathrm{Na}_{2} \mathrm{SO}_{4}$ for half an hour and concentrated under vacuum. The residue was purified by column chromatography $\left(\mathrm{SiO}_{2}\right.$; AcOEt/petroleum ether 1:2-2:1). The purified product URD12, obtained in 53\% yield, was identified by NMR, MS and elemental analysis.

MTT cell proliferation assay. The MTT assay was performed to determine the cytotoxicity based on the previously described method with minor modifications (14). In brief, $200 \mu \mathrm{l}$ of $\mathrm{H} 22$ cell suspension $\left(1 \times 10^{4}\right.$ cells) were added to 96-well roundbottomed plates (Corning Incorporated Costar ${ }^{\circledR} 3799$, Corning, $\mathrm{NY}$, USA) and each plate was incubated for $24 \mathrm{~h}$ at $37^{\circ} \mathrm{C}$ in a humidified $5 \% \mathrm{CO}_{2}$ atmosphere. Following incubation, $20 \mu \mathrm{l}$ per well of complete medium for controls or reagent with different concentrations for experimental groups were distributed in the 96-well plates and each plate was incubated for $48 \mathrm{~h}$ at $37^{\circ} \mathrm{C}$ in a humidified environment with $5 \% \mathrm{CO}_{2}$. Following incubation, 
Table I. Inhibitive effects of URD12 treatment on tumors.

\begin{tabular}{|c|c|c|c|c|c|c|c|}
\hline \multirow{2}{*}{ Groups } & \multicolumn{2}{|c|}{ No. of animals } & \multirow{2}{*}{$\begin{array}{c}\text { Dose } \\
(\mathrm{mg} / \mathrm{kg})\end{array}$} & \multicolumn{2}{|c|}{ Body weight (g) } & \multirow{2}{*}{$\begin{array}{c}\text { Tumor } \\
\text { weight (g) }\end{array}$} & \multirow{2}{*}{$\begin{array}{l}\text { Tumor weight } \\
\text { inhibition }(\%)\end{array}$} \\
\hline & Beginning & End & & Beginning & End & & \\
\hline Vehicle & 12 & 12 & - & $21.6 \pm 0.4$ & $22.3 \pm 1.1$ & $1.164 \pm 0.138$ & - \\
\hline $5-\mathrm{FU}$ & 12 & 6 & 25 & $21.0 \pm 0.4$ & $15.7 \pm 0.4^{\mathrm{a}}$ & $0.265 \pm 0.033^{\mathrm{a}}$ & 77.25 \\
\hline \multirow[t]{3}{*}{ URD12 } & 12 & 10 & 25 & $20.7 \pm 0.6$ & $21.9 \pm 1.3$ & $0.837 \pm 0.126$ & 28.10 \\
\hline & 12 & 11 & 50 & $21.3 \pm 0.7$ & $21.6 \pm 1.0$ & $0.694 \pm 0.107^{\mathrm{a}}$ & 40.37 \\
\hline & 12 & 12 & 100 & $21.3 \pm 0.5$ & $23.3 \pm 0.9$ & $0.651 \pm 0.047^{\mathrm{a}}$ & 44.10 \\
\hline
\end{tabular}

Data are shown as the mean \pm SE of $n$ animals. ${ }^{\mathrm{a}} \mathrm{P}<0.05$ compared with control group. 5-FU, fluorouracil.

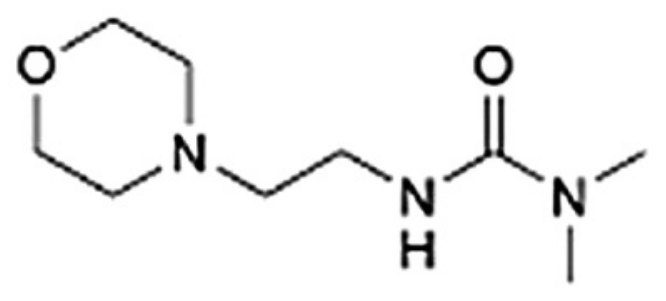

Figure 1. Molecular structure of URD12.

$20 \mu \mathrm{l}$ of $5 \mathrm{mg} / \mathrm{ml}$ MTT solution (dissolved in PBS and sterilized by filtration) were added to each well and the cultures were incubated in the dark for $4 \mathrm{~h}$ at $37^{\circ} \mathrm{C}$ in a humidified environment with $5 \% \mathrm{CO}_{2}$. The culture medium was removed from the wells and replaced with $150 \mu \mathrm{l}$ of dimethyl sulfoxide (DMSO). Following agitation for $10 \mathrm{~min}$, the absorbance of each well was measured at $490 \mathrm{~nm}$ using a Spectra Max 190 plate reader (Molecular Devices, Sunnyvale, CA, USA). The cell inhibition rate was calculated using the formula: cell inhibition rate $=$ (1-(absorbance of experimental wells)/(absorbance of control wells) $\times 100 \%$. The assays were performed at least three times in quadruplicates to determine the $\mathrm{IC}_{50}$ value. The $\mathrm{IC}_{50}$ value was calculated from the indicated concentrations using the method described by Bliss (15).

Effect of URD12 on solid tumor growth inhibition (16-17). Animals were divided into 5 groups ( $\mathrm{n}=12$ per group). Under sterile conditions, the animals were injected subcutaneously in the right forelimb with $1 \times 10^{6} \mathrm{H} 22$ hepatocellular carcinoma cells in sterile physiological saline (aspirated from 7-day-old $\mathrm{H} 22$ ascites tumors in mice) at $0.2 \mathrm{ml} /$ mouse. After $24 \mathrm{~h}$ of tumor inoculation, URD12 $(25,50$ or $100 \mathrm{mg} / \mathrm{kg})$ was dissolved in 5\% DMSO and administered intraperitoneally for 10 days in mice transplanted with $\mathrm{H} 22$ tumor cells. 5-Fluorouracil (5-FU) $(25 \mathrm{mg} / \mathrm{kg})$ was used as a positive control. The negative control was injected with 5\% DMSO. On the 11th day, blood samples were drawn from orbit to separate serum. The samples were maintained at $-80^{\circ} \mathrm{C}$ in preparation for the tests for TNF- $\alpha$ and IL-2 (R\&D ELISA Kit, R\&D Systems, Minneapolis, MN USA). The animals were then sacrificed. Tumors, thymus and spleen were extirpated and weighed. The inhibition ratio (\%) was calculated using the

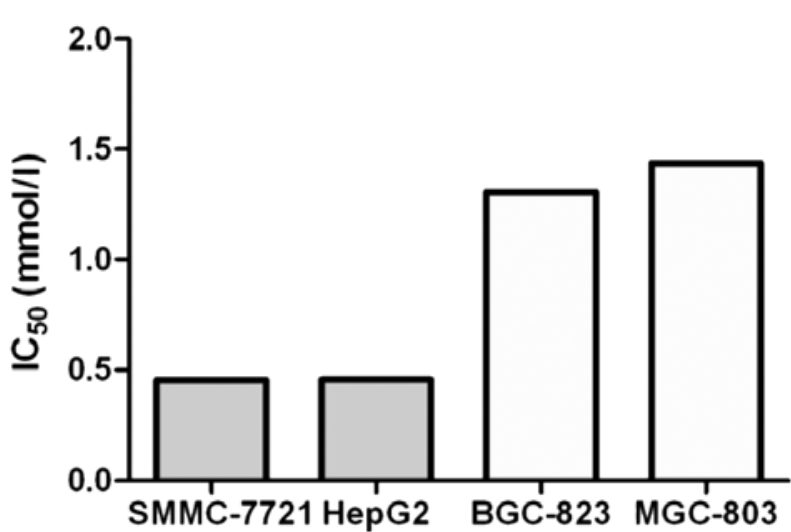

Figure 2. The cytotoxicity of URD12 on tumor cells in vitro. For each tumor cell, 6 concentrations were used.

formula: inhibition ratio $(\%)=(\mathrm{C}-\mathrm{T}) / \mathrm{C} \times 100 \%$, where ' $\mathrm{T}$ ' and ' $\mathrm{C}$ ' are the average tumor weights of the treated and control groups, respectively. Organ coefficient = organ weight $/$ body weight $\mathrm{x} 100 \%$.

Statistical analysis. Results were expressed as the mean \pm SE. Statistical analysis was performed using the Student's t-test. Differences were considered significant if $\mathrm{P}<0.05$.

\section{Results}

Inhibition of cell proliferation by URD12 treatment. It was found that URD12 was an effective anti-proliferative agent. Exposure to URD12 for $48 \mathrm{~h}$ inhibited tumor cell growth in all four lines tested (Fig. 2).

Proliferation/survival was assessed using the MTT assay. MTT is a pale yellow substrate that can be cleaved by living cells to yield a dark blue formazan product. This colorimetric change reflects the proliferation/survival of viable cells. $\mathrm{IC}_{50}$ concentrations varied from approximately $0.456 \mathrm{mmol} / \mathrm{l}$ for SMMC-7721 to $1.437 \mathrm{mmol} / \mathrm{l}$ for MGC-803.

In vivo antitumor activity. URD12 significantly suppressed growth of the H22 tumor, and URD12 was more effective at $100 \mathrm{mg} / \mathrm{kg}$ than at lower doses. Significant differences were observed between the treatment and control groups (Fig. 3A). 
A

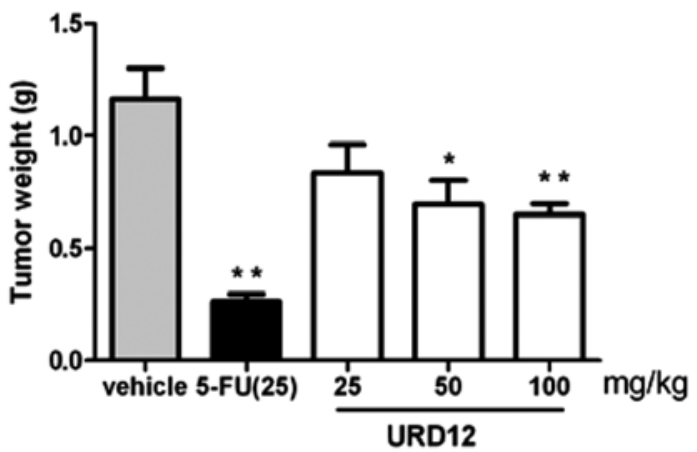

C

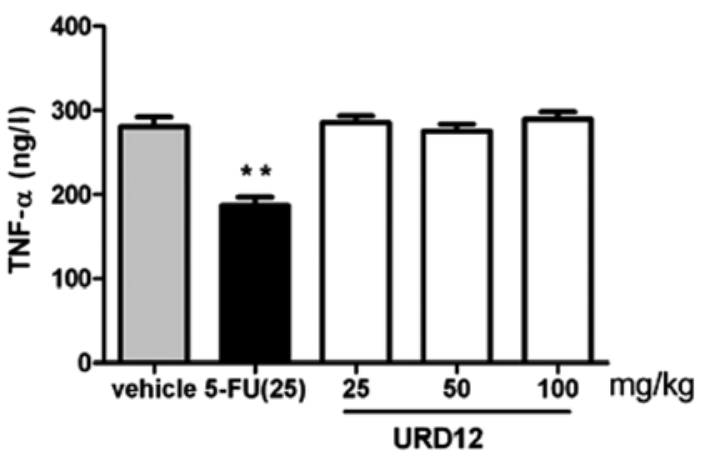

B

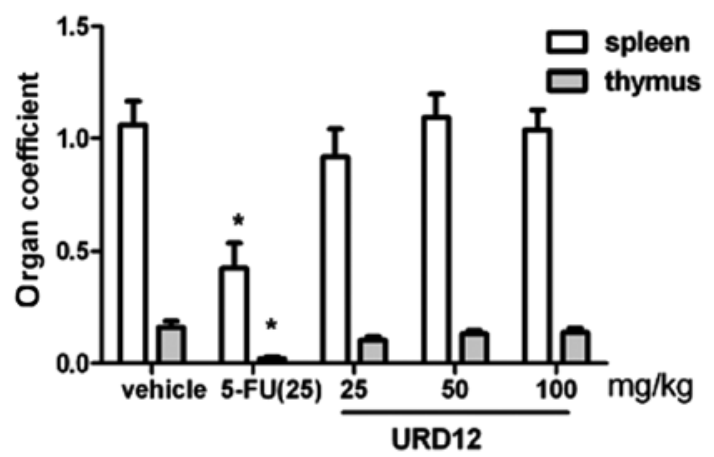

D

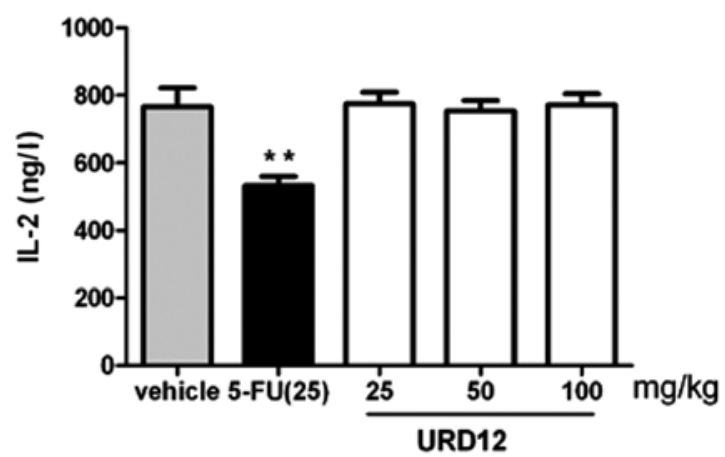

Figure 3. (A) The effect of URD12 on H22 tumor-bearing mice. (B) Tumor growth inhibitory effect of URD12 on H22 tumor-bearing mice. (C and D) Effects of URD12 on organ coefficient of H22 tumor-bearing mice. Data are shown as the mean \pm SE of $n$ animals (vehicle control n=12; 5-FU n=6; URD 25, 50 or $100 \mathrm{mg} / \mathrm{kg} \mathrm{n}=10,11,12)$. All treated groups were compared with the vehicle control group. ${ }^{*} \mathrm{P}<0.05,{ }^{* * *} \mathrm{P}<0.01$.

In addition, a marked decrease in body weight was observed in the 5-FU-treated group compared with the control group, whereas no decrease was observed in the URD12-treated groups (Table I). This finding indicates that URD12 may be a promising antitumor agent with low toxicity.

To evaluate the possible toxicological effects of URD12 on mouse organs, we extirpated the spleen and thymus and weighed them after the mice had been sacrificed. The organs were then analyzed for gross anatomy. No significant changes in organ weight were observed in animals treated with URD12, whereas 5-FU treatment reduced the body weight and spleen and thymus coefficients compared with the control group (Fig. 3B). The serum levels of TNF- $\alpha$ and IL-2 in the 5-FU group were low, and URD12 treatment groups exhibited no marked change (Fig. 3C and D).

Since Mosmann used a tetrazolium salt to develop a quantitative colorimetric assay for detecting mammalian cell survival and proliferation, this method has been used widely (18). The main advantages of the colorimetric assay are its rapidity, precision and lack of any radioisotope. We used the MTT assay to detect the activity of URD12 on tumor cells. Our results revealed that URD12 inhibited the growth of the four tumor cell lines investigated.

\section{Discussion}

Studies have shown that when the body generates a certain volume of tumor cells, anti-tumor immune response develops.
As a result, cancer patients experience more favorable outcomes in the early or catabatic stage of tumor progression, and following surgery. However, when the tumor progresses to a certain extent, the majority of patients undergo immune inhibition due to a variety of immune substances secreted by the tumor, and tumor patients suffer from collapse of immune systems including abnormal growth of spleen and shrinking of thymus. With the development of immunology and molecular biology, it has generally been accepted that the immunity of the body is closely correlated to the generation and development of cancer, and that dysfunction of the immune system is a crucial factor leading to cancer. When tumor cells invade the body, the immune system responds to the outside antigens. However, with the growth of the tumor, immune functions of the body are inhibited by the tumor in a variety of ways. The compensative outward-transfer of mature and nearly mature lymphocytes in the thymus and certain active factors generated in the tumor lead to the shrinking of the thymus. In addition, the inhibitory substances released by the tumor and the tumor-distinctive inhibitors produced by induction of the body result in an abnormal increase of the spleen index in tumor-bearing mice.

H22 cells are mouse hepatocarcinoma cells and are generally used for tumor research and drug screening (19). The immune organ coefficient is an index with which to initially judge the body's immune function. The thymus and spleen are essential immune organs. The main function of the thymus is to generate lymphocytes and to secrete thymosin, which is 
mainly associated with cell immunity. B lymphocytes play a more significant role in the spleen in that they are closely correlated to body fluid immunity. The above-mentioned experiments revealed that the spleen index increased abnormally and the thymus shrank in tumor-bearing mice. Since the antitumor effect of URD12 was more marked on hepatoma than on gastric carcinoma, an antitumor evaluation in vivo was carried out. The results showed that when treated with URD12, mouse immune organs were not inhibited, and their body weight did not markedly decrease. Compared with 5-FU, the antitumor activity of URD12 was weak, but it had substantially less toxicity.

A major complication of chemotherapy is toxicity to normal cells, which is due to the lack of specificity of drug actions between normal and malignant cells. This event often impacts the efficacy of the treatment and even leads to treatment failure in certain patients. One of the requirements of cancer chemopreventive agents is effective clearance of damaged or malignant cells through cell cycle inhibition or induction of apoptosis without, or with less, toxicity to normal cells (20-21). Our data indicate that URD12, a urea derivative bearing a morpholine moiety for enhanced bioactivity, exhibits marked antitumor activity without obvious immune inhibition.

\section{References}

1. Hackbarth CJ, Chen DZ, Lewis JG, et al: N-alkyl urea hydroxamic acids as a new class of peptide deformylase inhibitors with antibacterial activity. Antimicrob Agents Chemother 46: 2752-2764, 2002.

2. Yang J, Di F, He R, et al: Efffect of addition of low-dose rosiglitazone to sulphonylurea therapy on glycemic control in type 2 diabetic patients. Chin Med J (Engl) 116: 785-787, 2003.

3. Cook JW, Sterman DH, Singhal S, Smythe WR and Kaiser LR: Suramin inhibits the growth of malignant mesothelioma in vitro, and in vivo, in murine flank and intraperitoneal models. Lung Cancer 42: 263-274, 2003.

4. Easmon J, Purstinger G, Heinisch G, et al: Synthesis, cytotoxicity, and antitumor activity of copper(II) and iron(II) complexes of (4) $\mathrm{N}$-azabicyclo[3.2.2]nonane thiosemicarbazones derived from acyl diazines. J Med Chem 44: 2164-2171, 2001.

5. Fujita F, Fujita M, Inaba H, Sugimoto $T$, Okuyama $Y$ and Taguchi T: [Combination chemotherapy of HO-221, a derivative of benzoylphenylurea with various anticancer agents against human cancer xenografts in nude mice]. Gan To Kagaku Ryoho 18: 2263-2270, 1991.
6. Gnewuch CT and Sosnovsky G: A critical appraisal of the evolution of N-nitrosoureas as anticancer drugs. Chem Rev 97: 829-1014, 1997.

7. Jiang JD, Denner L, Ling YH, et al: Double blockade of cell cycle at $\mathrm{g}(1)$-s transition and $\mathrm{m}$ phase by 3 -iodoacetamido benzoyl ethyl ester, a new type of tubulin ligand. Cancer Res 62: 6080-6088, 2002.

8. Jiang JD, Roboz J, Weisz I, et al: Synthesis, cancericidal and antimicrotubule activities of 3-(haloacetamido)-benzoylureas. Anticancer Drug Des 13: 735-747, 1998.

9. Okada H, Koyanagi T and Yamada N: Synthesis and antitumor activities of prodrugs of benzoylphenylureas. Chem Pharm Bull (Tokyo) 42: 57-61, 1994.

10. Olaharski AJ, Mondrala ST and Eastmond DA: Chromosomal malsegregation and micronucleus induction in vitro by the DNA topoisomerase II inhibitor fisetin. Mutat Res 582: 79-86, 2005.

11. Singh SK, Ruchelman AL, Li TK, Liu A, Liu LF and LaVoie EJ: Nitro and amino substitution in the D-ring of 5-(2- dimethylaminoethyl)-2,3-methylenedioxy-5H-dibenzo[c,h][1,6]naphthyridin-6-ones: effect on topoisomerase-I targeting activity and cytotoxicity. J Med Chem 46: 2254-2257, 2003.

12. Toth JE, Grindey GB, Ehlhardt WJ, et al: Sulfonimidamide analogs of oncolytic sulfonylureas. J Med Chem 40: 1018-1025, 1997.

13. Cao P, Huang XF, Ding H, et al: Synthesis and cytotoxic evaluation of substituted urea derivatives as inhibitors of human-leukemia K562 cells. Chem Biodivers 4: 881-886, 2007.

14. Si-Tu ZQ and Wu JZ (eds): Cell Culture. 2nd edition. World Publishing Corporation, Xi'an, pp200-201, 2007.

15. Bliss C: The comparison of dosage-mortality data. Ann Appl Biol 22: 307-333, 1935.

16. Tian Z, Si J, Chang Q, et al: Antitumor activity and mechanisms of action of total glycosides from aerial part of Cimicifuga dahurica targeted against hepatoma. BMC Cancer 7: $237,2007$.

17. Long L and Li Q: The effect of alkaloid from Oxytropis ochrocephala on growth inhibition and expression of PCNA and p53 in mice bearing H22 hepatocellular carcinoma. Yakugaku Zasshi 125: 665-670, 2005.

18. Mosmann T: Rapid colorimetric assay for cellular growth and survival: application to proliferation and cytotoxicity assays. J Immunol Methods 65: 55-63, 1983.

19. Hirohashi S, Shimosato Y, Kameya T, et al: Production of alphafetoprotein and normal serum proteins by xenotransplanted human hepatomas in relation to their growth and morphology. Cancer Res 39: 1819-1828, 1979.

20. Srivastava JK and Gupta S: Tocotrienol-rich fraction of palm oil induces cell cycle arrest and apoptosis selectively in human prostate cancer cells. Biochem Biophys Res Commun 346: 447-453, 2006.

21. Stolarska M, Mlynarski W,Zalewska-Szewczyk B and Bodalski J: Cytoprotective effect of amifostine in the treatment of childhood neoplastic diseases - a clinical study including the pharmacoeconomic analysis. Pharmacol Rep 58: 30-34, 2006. 